\title{
The Relationship of Water Quality to Epipelic Diatom Assemblages in Cebong Lake, Dieng Indonesia
}

\author{
Tri Retnaningsih Soeprobowati ${ }^{1,2,3 *}$, Hartuti Purnaweni ${ }^{1}$, \\ Jumari Jumari ${ }^{2,3}$, Kenanga Sari ${ }^{3}$ \\ ${ }^{1}$ School of Postgraduate Studies Universitas Diponegoro, Semarang Indonesia \\ ${ }^{2}$ Department Biology, Faculty of Science and Mathematics, Universitas Diponegoro, Semarang Indonesia \\ ${ }^{3}$ Center for Paleolimnology (CPalim), Universitas Diponegoro, Semarang Indonesia
}

Received: 16 January 2021

Accepted: 13 May 2021

\begin{abstract}
Indonesia has 147 volcanoes by which approximately 76 are active, including volcanoes in Dieng plateau, Java. Dieng is surrounded by complex volcanic mountainous as the highest plateau in Indonesia. The activity of the volcano affected the formation of lakes in the Dieng plateau, one of them is Cebong Lake. Similar to other lakes in Dieng, Cebong Lake is an important resource for water supply, ecotourism, and irrigation for potato plantation. The multiple drivers of physical parameters of water quality interact across multiple scales affected the diversity of diatom. This study aimed to determine the relationship between water quality and epipelic diatom assemblage in Cebong Lake. The diatom samples were collected from the different sediment surface sites from Cebong Lake to show a diatom distribution associated with physicochemical parameters of water quality. The sediment sample was digested using hot $\mathrm{HCL}$ and $\mathrm{H}_{2} \mathrm{O}_{2} 10 \%$ to remove organic material, mounted with Naphrax, and identification/enumeration of diatom using a microscope under 1,000 magnification for at least 300 valvae were found. The surface epipelic diatom community was represented by 60 taxa belongs to 27 genera. The diatom indices that represent $>70 \%$ species from Cebong Lake were IDG, IPS, TDI, IBD. Based on the diatom indices, Cebong Lake was in the $\beta$ mesosaprobic status. This is supported by the concentration of TN and TP that was in the mesotrophic status. Diatom assemblages from Cebong lake were characterized by the presence of Achanthidium microcephalum, Brachysira brebissoni, Aulacoseira tenella, and Denticula tenuis that were correlated with $\mathrm{NH}_{3}$. The occurrence of Staurosira psedoconstruens was correlated to the turbidity, DO, and $\mathrm{pH}$. Nitzchia palea was correlated with temperature, while Achanthidium minutissimum, Staurosira construens, and Fragillaria tenera are being closer to each other and were associated mainly with TP. Diatom species had specific tolerance
\end{abstract}

*e-mail: trsoeprobowati@live.undip.ac.id 
to the environmental parameter and their response in species and communities level had indicated the water quality of the lakes.

Keywords: epipelic, diatom, Cebong Lake Dieng, water quality

\section{Introduction}

Lake is a classical method for water quality assessment of physical, chemical, and biological approaches. Physical and chemical measurement cannot represent the water quality at the full range of variability [1-2], and is unable to detect the source of pollution [3]. Biological assessment integrates physical and chemical conditions overtimes [2, 4]. Using organism for water quality assessment is more effective and efficient in aquatic ecosystem assessment. A bioindicator is the organism, or part of the organism, or communities that are able to indicate a location, state, and environmental quality [5-7]. There are four kinds of bioindicators, i.e. pollution bioindicator- to detect the presence of pollutants; environmental bioindicatorto detect and monitor the state of environmental change; ecological bioindicator- to detect natural changes and their impacts demonstrate the impact of a stressor to the biota and monitor the long-term stressor effect on biota; and biodiversity bioindicator- to identify the diversity of taxa in such region and to monitor biodiversity changes [7].

Bioindicators are utilized to evaluate human effects on the environment. In terms of an aquatic ecosystem, particularly in lake ecosystem, the organism or groups of organisms that are usually used as a bioindicator of water quality are phytoplankton [8-11], microbes [1213], invertebrates [14-16], diatoms [17-28], macrophytes [29-30], and fish [31].

Lake's water quality affected the composition and abundance of diatoms. Diatom is a microalga that can be found in various habitats from humid soils to the freshwater and seawater ecosystem [32]. The unique feature of diatoms is the siliceous cell wall, photonic structure, and porous in the frustule [33]. Diatoms have an important role in the aquatic ecosystem as the main oxygen producer [34-35].

In the water quality monitoring program diatoms had been used as bioindicators due to their quick response to the environmental changes [25, 36-39], their correlated with the pollutant [32]. The advantages of using diatoms as a bioindicator for water quality, reflected the water quality and integrated effect of different stress, whereas physico-chemical parameter only indicated the water quality when the samples were taken and measured. Secondly, they provide a direct impact on the changes of ecological condition, and thirdly, provide quick, and relatively easy to apply water quality assessment [40]. Furthermore, the application for water quality assessment had developed [37]. Since 1970 some kind of multivariate analysis had been developed to determine the relationship between the diatoms and environmental variables [22, 41], or paleoreconstruction analysis [21, 42-44].

Diatom has a strong response to environmental changes, such as eutrophication, acidification, or heavy metals contamination. Those responses can be detected with the combination of environmental factors such as $\mathrm{pH}$, temperature, dissolved oxygen, turbidity, conductivity, and heavy metals [45].

Diatom has been applied for ecological quality analysis for more than decades in several countries in a temperate region. However, study of the relationship of water quality parameters related to diatom assemblages for tropical lakes are required prior to paleoecological studies. The purpose of this research is to identify and evaluate the environmental variables related to diatom assemblages' in Cebong Lake.

\section{Material and Methods}

\section{Study Area}

Dieng area administratively is located in the west zone of Mount Serayu at the coordinate of $7^{\circ} 12^{\prime \prime S}$ and $109^{\circ} 54^{\prime \prime} \mathrm{E}$ with a total area of 54,974.24 Ha. Dieng is located in 6 towns of Temanggung, Kendal, Pekalongan, Batang, Banjarnegara, and Wonosobo. The biggest area is located in Pekalongan town 18,786.04 Ha [46-47]. Dieng plateau is separated into two districts Banjarnegara and Wonosobo, Central Java Indonesia [48]. Dieng plateau area has a function for agriculture and strategic protection area for environmental carrying capacity. Both Banjarnegara and Wonosobo are included in priority areas based on Government regulation caused by the critical slope in Banjarnegara regency higher than Wonosobo and have a significant impact on the vulnerability of cities because of potential runoff from slope and agriculture plantation [46].

Dieng volcanic complex was formed in the Late Quaternary to Recent. The Dieng Plateau has experienced a series of volcanic eruptions recorded from the 1800 s onwards, the last magmatic activity occurred about a century ago [49] Geomorphologically, the Dieng plateau area is surrounded by nine active volcanoes since young Pleistocene Jembangan Caldera with an altitude of 2,565 masl, temperature around $10^{\circ} \mathrm{C}-20^{\circ} \mathrm{C}$ [50] The geothermal resource in Dieng was recognized during Dutch colonial period 1964/1965 the area was identified as one of the geothermal prospects in Indonesia by UNESCO [51]. There are various volcanic lake around Dieng such as Warna, Pengilon, Dringo, Balekambang, Merdada, Swiwi, Siterus and 

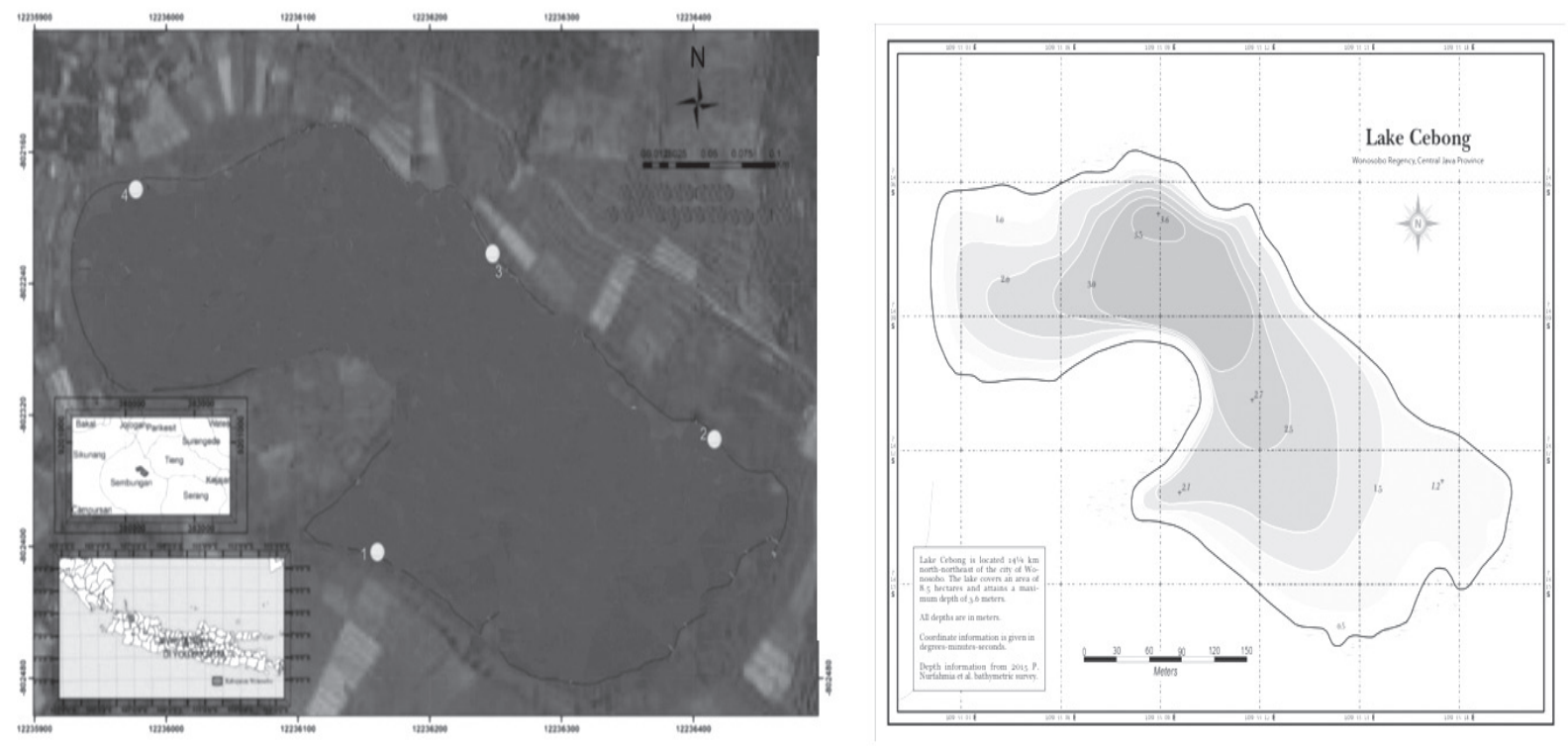

Fig. 1. Research sites in Cebong Lake, Dieng.

Menjer hydrothermal crater, hot spring was formed during a volcanic activity such as Cebong Lake [52-53].

Cebong Lake was formed by the eruption of Mount Prau, located in Sembungan Village, the highest village in Central Java, with an altitude of 2,123 masl [54]. Previously, the lake around $18 \mathrm{Ha}$ but, recently remaining around $12 \mathrm{Ha}$ surrounded by potato plantation and resident area [53]. Cebong Lake is located $14.25 \mathrm{~km}$ north-northeast of Wonosobo city. The lake covers an area of $8.5 \mathrm{Ha}$ and a maximum depth of 3.6 meters [55] (Fig. 1). During the dry season, the water for irrigation source for potato plantation has been carried out from Cebong lake but massive irrigation pumping caused decreasing the water level.

The catchment area of Cebong Lake has a slope of up to $30-40 \%$ used for agriculture and precipitation in Dieng Plateau is high around 3,917 $\mathrm{mm} /$ year, potentially caused erosion and runoff from the catchment area and accumulated in the lake. The problem in Cebong Lake is sedimentation that might be caused by various erosion processes, such as cliff erosion, soil erosion, or other erosion. Sediment in Cebong Lake can be rotten from potatoes or other plants decomposed by bacteria [55], which in turn, influence the water quality of the lake.

\section{Sampling Sites}

Water and sediment samples were collected from 4 sites in August 2020 (Fig. 1). Site 1 was an area near the potato plantation, Site 2 was the area near the camping ground, Site 3 was the area close to the inlet and potato plantation, and Site 4 was the outlet area. At every site, in-situ measurement of water quality of temperature, $\mathrm{pH}, \mathrm{DO}$, turbidity, conductivity were done with 3 replications. Water samples were collected for analysis of TN and TP. Water sampling was carried out at each station by the Indonesian National Standard, SNI 6989.57-2008: taking the surface water samples. The water samples were collected in $1 \mathrm{~L}$ clean plastic bottles, labeled, and then put into a cooler. The physicochemical parameters such as temperature, $\mathrm{pH}$, and dissolved oxygen were measured directly (in-situ) in the field. The surface sediment samples were collected randomly.

\section{Diatom Analysis}

Five (5) $\mathrm{mg}$ sediment samples were digested with $50 \mathrm{ml}$ of $10 \% \mathrm{HCL}$ at temperature $80^{\circ} \mathrm{C}-90^{\circ} \mathrm{C}$ for at least 2 hours, then the samples were rinsed using distilled water and digest with hot $10 \% \mathrm{H}_{2} \mathrm{O}_{2}(50 \mathrm{ml})$. The samples were cleaned with distilled water until aneutral $\mathrm{pH}$. The procedure followed Soeprobowati et al. [56]. All samples were mounted using Naphrax with refraction index 1,7 and identified with Olympus microscope at 1,000 magnification under immersion oil with the minimum enumeration of 300 valvae diatoms was counted [56]. The identification diatom with the help of identification book (57-66) and checked in AlgaBase.org [67].

\section{Data Analysis}

Shannon Wiener species diversity index (H') was calculated along with species richness, evenness, and dominance indices were performed using PAST 4.03 [68]. The species with a relative abundance lower than $2 \%$ were removed from the calculation. The data were carried out on the log-normal transformed abundance data, the species abundance (n) was log-transformed as $\mathrm{Y}=\log (\mathrm{n}+1)$. Canonical Correspondence Analysis (CCA) was chosen to explore the relationships amongst 
species and predicted variables [69], and to determine the relationship between diatom assemblages and measured ecological variables. OMNIDIA software version 6.0 was used to calculate the 18 water quality indices based on diatoms [70], as shown in Table 1.

In OMNIDIA software, all the indices were transformed to the range of 0 to 20 which indicate ecological and trophic status. The index score higher than 17 has a high ecological status and oligotrophic, 1517 has a good ecological status and oligo-mesotrophic, $12-15$ has a moderate ecological status and mesotrophic, 9-12 has poor ecological status and meso-eutrophic, and $<9$ has a bad ecological status and eutrophic (Table 2).

\section{Results and Discussion}

\section{Water Quality}

The water temperature of 4 research sites ranged between $17^{\circ} \mathrm{C}$ to $20^{\circ} \mathrm{C}$. The highest water temperature is at Site 2 (near the camping ground), and the lowest temperature is at Site 4 (outlet, Fig. 2). The temperature at Cebong Lake meets the criteria for water quality standards based on Indonesian Government Regulation Number 82 of 2001 for classes I, II, III, and IV which state that the water temperature is at a $3^{\circ} \mathrm{C}$ deviation from the natural conditions of the surrounding environment. The specific species responses of diatom for temperature are affected by interspecific interactions [91].

The dissolved oxygen (DO) concentration for Cebong Lake ranged from 6.9 to $7.8 \mathrm{mg} / \mathrm{L}$ (Fig. 2). Based on Government Regulation no. 82 of 2001 DO concentration is above the Class I water quality standard which states DO $6 \mathrm{mg} / \mathrm{L}$, and exceeds the Class II, III, and IV of water quality standards. DO level in aquatic waters is negatively correlated with water temperature. In the stratified lake, an increase of water temperature, decreasing the oxygen concentration. In this research, water temperature and DO were measured in the $20 \mathrm{~cm}$ depth, in where the epipelic diatoms were collected. In the littoral area, diatoms show high diversity and low dominance and benthic, periphytic species are dominant [71]. Climate change slightly influence the relationship between temperatures and DO concentration. This might affect the future ecological systems [92].

The $\mathrm{pH}$ value of Cebong Lake (5 -6) is in the border of Water Quality Standard as stated by Government Regulation No. 82 of 2001 for classes I, II, III, and IV which states the $\mathrm{pH}$ should be within the range of 6-9 and under standard for Site 2 and 3 (Fig. 3). The degree of acidity $(\mathrm{pH})$ of water indicates the presence of hydrogen ions in water. Cebong Lake tends to acidic lake due to the crater lake [53-55].

Table 1. Diatom indices evaluated for this research.

\begin{tabular}{|c|c|c|}
\hline Indices & Type of indices & References \\
\hline IBD (Biological Diatom Index) & General Pollution & {$[71]$} \\
\hline IPS (Specific Pollution Sensitivity Index) & General Pollution & {$[72]$} \\
\hline IDG (Generic Diatom Index) & General Pollution & {$[73]$} \\
\hline DES (Descy's Index) & General Pollution & {$[74]$} \\
\hline Sla. (Sládeček's Index) & Saprobity (BOD) & {$[75]$} \\
\hline IDS/E (Louis-Leclercq Diatomic Index) & Saprobity & {$[76]$} \\
\hline IDAP (Artois-Picardie Diatom Index ) & General Pollution & {$[77]$} \\
\hline EPID (Eutrophication/Pollution Index) & Pollution/Trophic status & {$[78]$} \\
\hline Lobo (Trophic-Saprobic index) & Eutrophication & {$[79]$} \\
\hline DI-CH (Swiss Diatom Index, Hurl.) & Trophic status & {$[80]$} \\
\hline Rott TI (Rott's Trophc Metric) & Trophic status & {$[81]$} \\
\hline Rott SI (Rott's Saprobic Metric) & Saprobic status & {$[82 \mathrm{v}$} \\
\hline TDIL (Tropic Diatom Index) & Saprobity & {$[83]$} \\
\hline WAT (Watanabe Index) & General Pollution & {$[84]$} \\
\hline Saprobity (BOD) & {$[85]$} \\
\hline CEE (Commission for Economical Community Metric - European Index) & Trophic status/eutrophication & {$[83]$} \\
\hline IDP (Pampean Diatom Index) & Organic pollution/eutrophication & {$[86]$} \\
\hline index & Trophic status & {$[87,88]$} \\
\hline
\end{tabular}


Table 2. Diatom indices score value and ecological and trophic status $[89,90]$.

\begin{tabular}{|c|c|c|}
\hline Index score & Ecological status & Trophic status \\
\hline$>17$ & High & Oligotrophic \\
\hline $15-17$ & Good & Oligo-mesotrophic \\
\hline $12-15$ & Moderate & Mesotrophic \\
\hline $9-12$ & Poor & Meso-Eutrophic \\
\hline$<9$ & Bad & Eutrophic \\
\hline
\end{tabular}

The results of the analysis of all sites form Cebong Lake ranged from 36-50 NTU (Fig. 4), has exceeded the threshold for water quality standard criteria based on Government Regulation Number 82 of 2001 for classes I, II, III, and IV which state turbidity of 10 NTU. Turbidity affected by high turbulence and water mixing which led to an increase in suspended particulate matter and the intensity of light entering the waters [93].
The ammonia $\left(\mathrm{NH}_{3}\right)$ at Cebong lake range from 19-32 $\mu \mathrm{g} / \mathrm{L}$ below the threshold of the water quality standard criteria based on Government Regulation Number 82 of 2001 for classes I $(500 \mu \mathrm{g} / \mathrm{L}$, Fig. 5). Ammonia has the potential for high toxic effects in waters [94]. The concentration of Ammonia influence the concentration of Total Nitrogen (TN). The lowest concentration of $\mathrm{TN}$ was at Site $2(655 \mu \mathrm{g} / \mathrm{L})$, and the highest concentration of TN was at Site 1 and 3 $(742 \mu \mathrm{g} / \mathrm{L}$, Fig. 5). Based on the TN concentration, Cebong Lake was in the mesotrophic level $(650-750 \mu \mathrm{g} / \mathrm{L})[95]$. The aquatic nitrogen concentration is naturally produced by the action of lightning, the decay of proteins, and the effect of nitrogen-fixing bacteria on ammonia. TN is an important parameter of eutrophic waters, particularly for those polluted by fertilizer run-off, animal wastes, and domestic sewage [21].

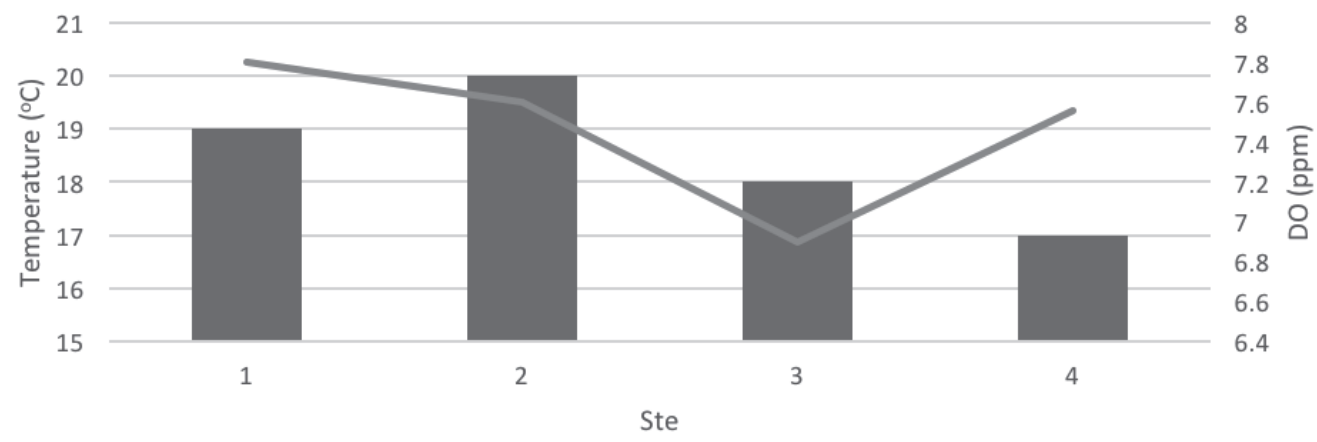

Temperature DO (ppm)

Fig. 2. Temperature of Cebong Lake, Dieng.

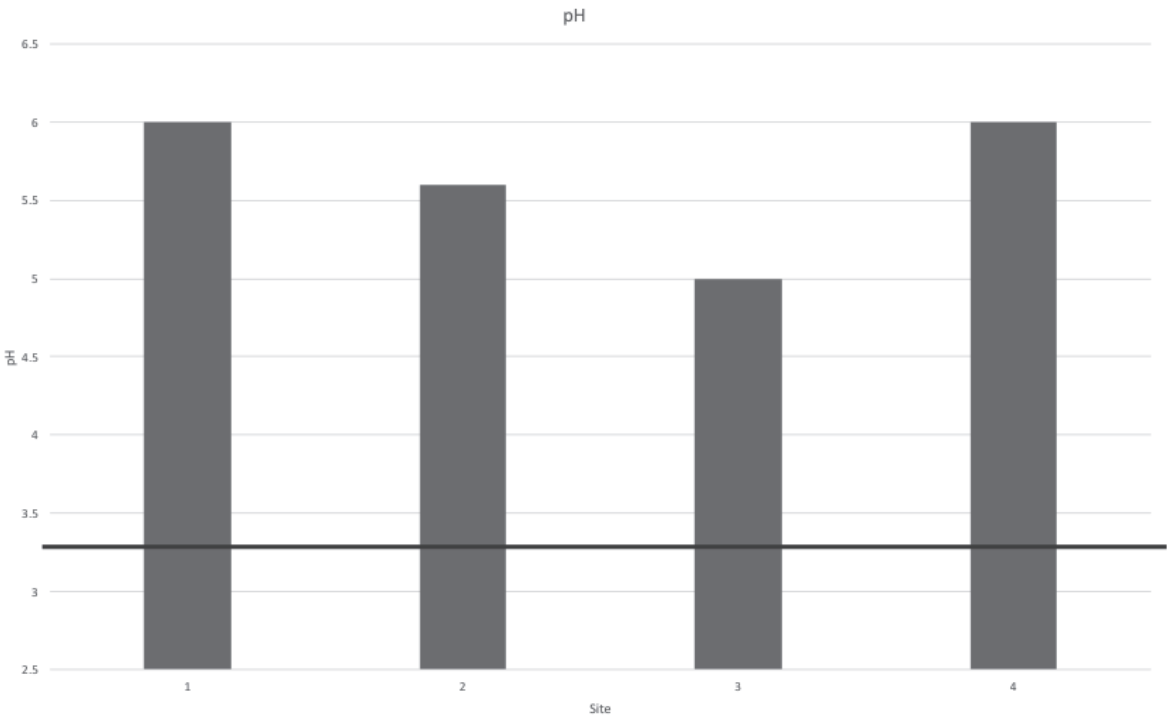

Fig. 3. pH of Cebong Lake, Dieng. 


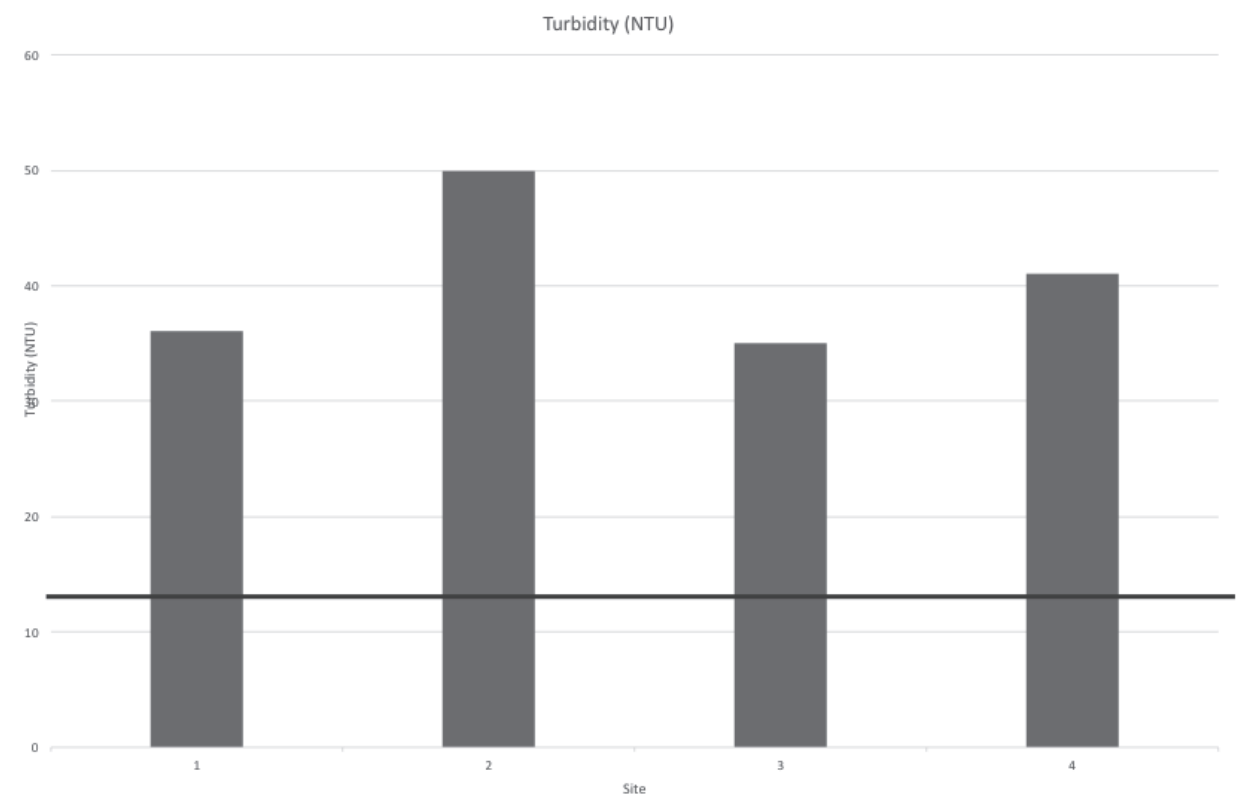

Fig. 4. Turbidity of Cebong Lake, Dieng.

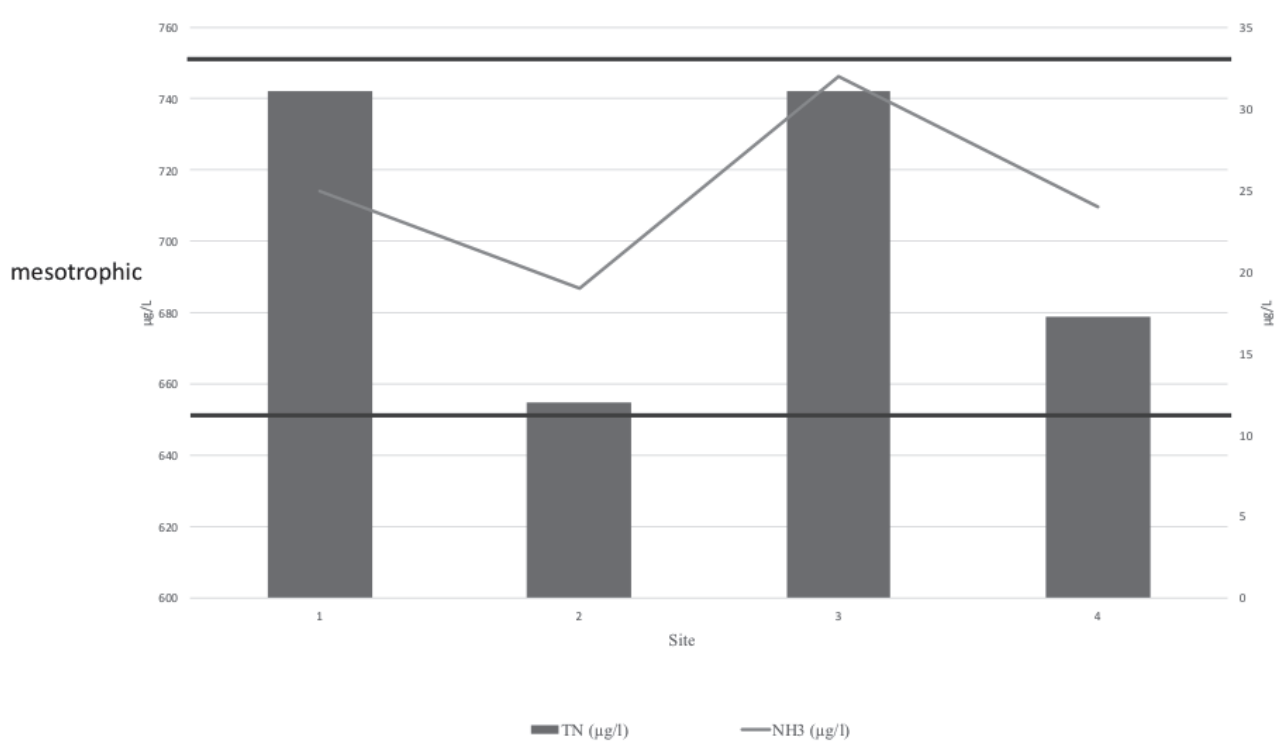

Fig. 5. The concentration of Ammonia $\left(\mathrm{NH}_{3}\right)$ and Total Nitrogen (TN) of Cebong Lake, Dieng.

Based on the Total Phosphorous (TP) concentration (in the range of 20-36 $\mu \mathrm{g} / \mathrm{L}$ ) Cebong Lake in the category of mesotrophic. The lakes in the oligotrophic state when the concentration of TP is $<10 \mu \mathrm{g} / \mathrm{L}$, and in the mesotrophic state when the TP concentration is 10-30 $\mu \mathrm{g} / \mathrm{L}$ [95]. The main sources which increase the phosphorus load in river water are the use of fertilizers, use of detergents, and domestic sewage [96].

\section{Diatom Assemblages}

A total of 60 diatoms from 27 genera were identified from Cebong Lake, that are distributed among the genus Achanthidium, Aulacoseira, Brachysira, Cacconeis,
Caloneis, Cymbella Denticula, Diploneis, Discostella, Encyonema, Encyonopsis, Ephitemia, Eunotia, Fragillaria, Frustulia, Gomphonema, Kobayasiella, Luticola, Melosira, Navicula, Nitzchia, Pinnularia, Rhopalodia, Sellaphora, Stauroneis, Staurosira and Surirella (Fig. 2). Only 13 species were commonly found with relative abundance $>2 \%$, i.e. Achnanthidium microcephalum (10.79\%), A. minutissimum (11.39\%), Aulacoseira tenella (6.38\%), Brachysira brebissoni (4.37\%), Denticula tennuis (3.14\%), Encyonema gracile (2.87\%), Fragillaria tenera $(3.84 \%), F$. pinnata (10.61\%), Kobayasiella micropunctata (3.05\%), Nitzchia palea (4.76\%), Staurosira construens (9.21\%), S. eliptica (6\%), and S. pseudoconstruens (2.58\%, Fig. 7). 


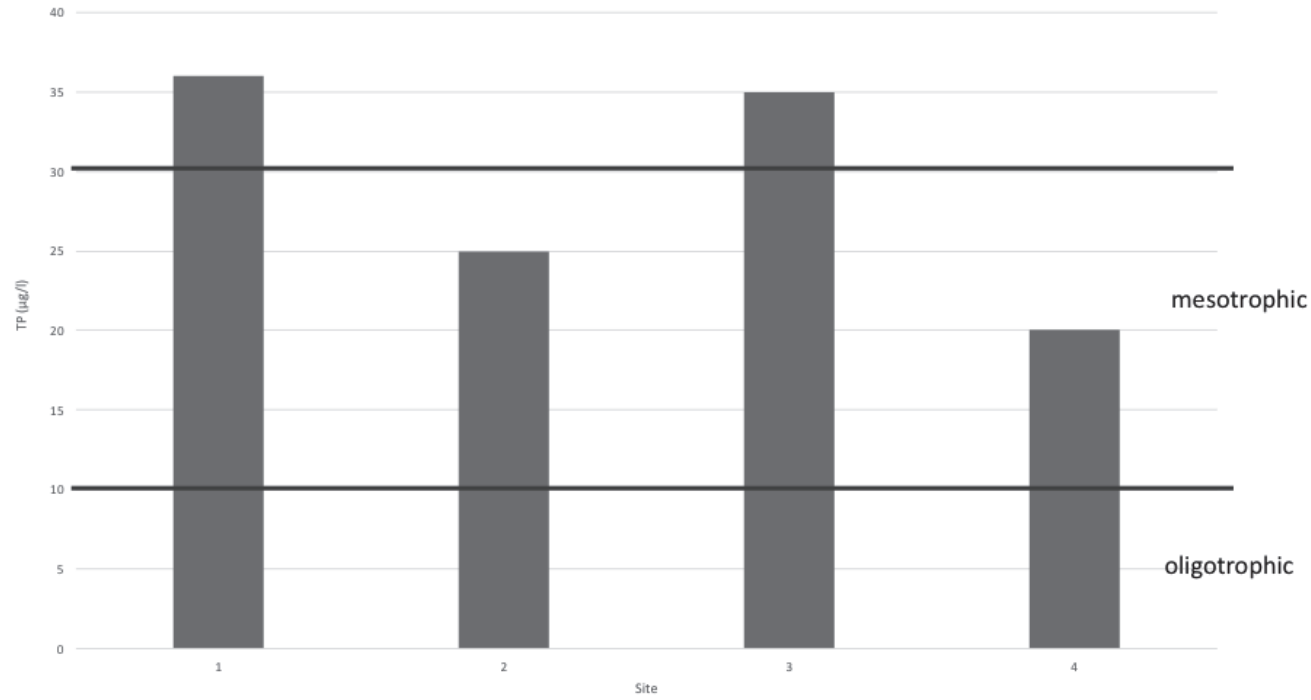

Fig. 6. The concentration of Total Phosphorous (TP) of Cebong Lake Dieng, Java.

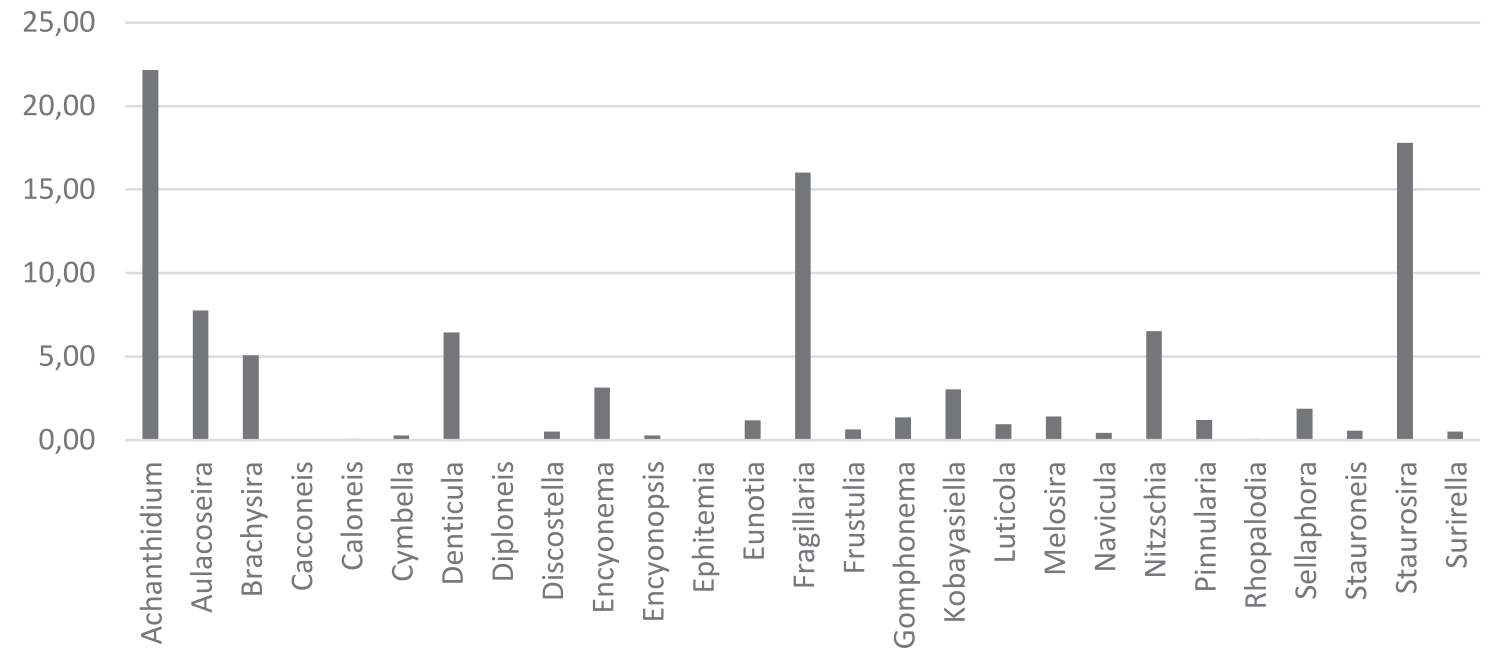

Fig. 7. The relative abundance of diatom species in Cebong Lake, Dieng.

In general, $A$. minutissimum was the most abundant and the most frequent species in all the examined sites from potato plantation, camping ground, and outlet. At Site 1 (near plantation area), A. minutissimum was dominant $(10.5 \%)$ and followed by $N$. palea $(8.83 \%)$. At Site 2, A, minuttisimum has the relative abundance of $16.33 \%$ following $S$. eliptica (16.44\%). Site 4 had diverse composition and dominated by $F$. pinnata $(22.67 \%)$.

In Brazilian reservoirs, A. minutissimum usually has an optimum growth at oligotrophic condition, $\mathrm{pH}$ around 7.5, conductivity around $29 \mu \mathrm{S} \mathrm{cm}-1$, temperature around $24.2^{\circ} \mathrm{C}$ [97]. A. minutissimum morphotypes exhibit different ecological preferences, therefore the correct identification led to the correct biogeographical distribution $[38,98]$.

The lowest Shannon-Wiener Diversity Index (H') was 2.53 at Site 1 indicated an impact of potatoes plantation and the highest $H^{\prime}$ was 3.22 at Site 4 that is more diverse near the outlet. The impact of agriculture was shown by the highest TN concentration $(742 \mu \mathrm{g} / \mathrm{L})$ at Site 1 and Site 3, whereas TN at Site 2 was $655 \mu \mathrm{g} / \mathrm{l}$, and Site 4 was $679 \mu \mathrm{g} / \mathrm{l}$, respectively (Fig. 5). A high nutrient influences the diatom composition. The occurrence of $N$. palea at Site 1 indicated a high nutrient level [99]. This was in-line with the highest concentration of TN at Site 1 (Fig. 5). $N$. palea is a cosmopolite diatom used as a bioindicator of water quality due to their tolerance of pollutant [100]. $N$. palea was widespread in the different environmental gradient levels and resistant to organic and heavy metals pollution, and have been frequently recorded in eutrophic lakes [101, 102].

\section{Diatom Indices}

Eighteen diatom indices were calculated with OMNIDIA, however not all the indices were encountered diatom species from Cebong Lake. 
The number of species included in the index calculation indicated the efficiency resulting metric that explained the ecological status. The diatom index scores of 4 research sites from Cebong Lake Dieng are shown in Table 3. The value of diatom indices was different according to the percentage of species used in the calculation of indices. The indices that included the highest amount of species diversity with more than $70 \%$ identified species were IDG, IPS, TDI, IBD. These indices were also provided a better results on the reflection of water quality in Ethiopia [103], Turkey
[104], and China [105]. TDI had applied to determine water quality upstream of Cileungsi River, West Java that classified from good to poor condition [106]. The indices that are only supported by $50 \%$ or less are Descy, IDS/E, IDAP, Lobo, DI-CH, Rott SI, PTI, PSI, TDIL, CEE,WAT, PDI, SHE, and EPI-L. This means that those indices are not applicable for tropical lakes, that consist of specific species, which are not found in the temperate lakes.

Based on the IBD, IPS, and IDG indices, Cebong Lake has a moderate to a high ecological status.

Table 3. The diatom indices scores at 4 research sites from Cebong Lake Dieng and corresponding ecological status (high: $>17$, good: 15-17, moderate: $12-15$, poor: $9-12$, and bad: $<9$ ).

\begin{tabular}{|c|c|c|c|c|c|c|c|c|}
\hline & \multicolumn{2}{|c|}{$\mathrm{TC} 1$} & \multicolumn{2}{|c|}{ TC2 } & \multicolumn{2}{|c|}{$\mathrm{TC} 3$} & \multicolumn{2}{|c|}{ TC4 } \\
\hline Number of species & \multicolumn{2}{|c|}{24} & \multicolumn{2}{|c|}{36} & \multicolumn{2}{|c|}{23} & \multicolumn{2}{|c|}{50} \\
\hline Number of genera & \multicolumn{2}{|c|}{17} & \multicolumn{2}{|c|}{22} & \multicolumn{2}{|c|}{16} & \multicolumn{2}{|c|}{25} \\
\hline population & \multicolumn{2}{|c|}{43500} & \multicolumn{2}{|c|}{68625} & \multicolumn{2}{|c|}{22500} & \multicolumn{2}{|c|}{67550} \\
\hline Diversity & \multicolumn{2}{|c|}{4.02} & \multicolumn{2}{|c|}{3.96} & \multicolumn{2}{|c|}{3.64} & \multicolumn{2}{|c|}{4.65} \\
\hline \multirow[t]{2}{*}{ Evenness } & \multicolumn{2}{|c|}{0.88} & \multicolumn{2}{|c|}{0.77} & \multicolumn{2}{|c|}{0.81} & \multicolumn{2}{|c|}{0.81} \\
\hline & \% Species & Index & $\%$ Species & Index & $\%$ Species & Index & $\%$ Species & Index \\
\hline IBD & 79.2 & 15.6 & 69.4 & 15.3 & 69.6 & 17.8 & 68 & 15 \\
\hline IPS & 91.7 & 15.5 & 83.3 & 15.8 & 91.3 & 18.2 & 84 & 15.7 \\
\hline IDG & 100 & 13.5 & 97.2 & 15.1 & 100 & 16 & 100 & 15.1 \\
\hline Descy & 45.8 & 17.1 & 36.1 & 18.2 & 34.8 & 18.7 & 32 & 18.8 \\
\hline Sla & 50 & 14.6 & 50 & 14.5 & 43.5 & 15.3 & 54 & 15.4 \\
\hline IDS/E & 41.7 & 3.82 & 47.2 & & 30.4 & & 46 & 3.93 \\
\hline IDAP & 29.2 & 10.1 & 22.2 & 12.2 & 21.7 & 12.3 & 20 & 9.2 \\
\hline EPID & 21.7 & 16 & 50 & 16.4 & 39.1 & 17.7 & 56 & 16.3 \\
\hline Lobo & 10 & 19.7 & 27.8 & 18.8 & 13 & 19.9 & 32 & 14.2 \\
\hline DI-CH & 45.8 & 15.9 & 38.9 & 15 & 39.1 & 16.8 & 36 & 15.7 \\
\hline Rott TI & 50 & 10.1 & 50 & 12.9 & 43.5 & 14.5 & 54 & 13.1 \\
\hline Rott SI & 45.8 & 17.1 & 38.9 & 17.8 & 34.8 & 17.9 & 44 & 17.8 \\
\hline PTI & 33.3 & 13 & 36.1 & 10 & 39.1 & 14.5 & 46 & 12.9 \\
\hline PSI & 54.2 & 15.4 & 36.1 & 15.7 & 34.8 & 17.1 & 44 & 17.1 \\
\hline TDIL & 33.3 & 13 & 25 & 13.5 & 26.1 & 14 & 34 & 11.3 \\
\hline CEE & 54.2 & 15.4 & 44.4 & 16.5 & 43.5 & 17.5 & 44 & 15.7 \\
\hline WAT & 25 & 10.6 & 22.2 & 10.5 & 17.4 & 14 & 18 & 10.3 \\
\hline TDI & 79.2 & 8.1 & 75 & 11.1 & 78.3 & 17.5 & 76 & 10.5 \\
\hline TDI4 & 58.3 & 11.2 & 55.6 & 11.3 & 56.5 & 13.6 & 56 & 11.6 \\
\hline LTDI2 & 62.5 & 10.1 & 58.3 & 10.2 & 60.9 & 11.8 & 60 & 10.2 \\
\hline PDI & 37.5 & 13.1 & 36.1 & 13.8 & 34.8 & 16.2 & 40 & 13 \\
\hline SHE & 45.8 & 15 & 44.4 & 15.2 & 43.5 & 14.6 & 42 & 15.8 \\
\hline EPI-L & 11.7 & & 22.2 & & 21.7 & 14.6 & 24 & \\
\hline ACID & 30 & & 75 & & 73.9 & 16.1 & 74 & \\
\hline
\end{tabular}


However, based on TDI, only TC3 in a high ecological status, whereas TC1, TC2, and TC4 in a poor condition. Based on the diatom indices, Cebong Lake is in the $\beta$ mesosaprobic status. At site 1 , the $\beta$ mesosaprobic status was indicated by the occurrence of $A$. microcephala, A. minustissima, Aulacoseira ambigua, A. granulata, Cymbella turgidula, Denticula kuetzingii, Fragillaria cappucina, Nitzschia liebethruthii, S.cosntruent, S. elliptica, and Staurosirella pinnata (previously known as $F$. pinnata), and $N$. rhyncocephala for Site 2 [107, OMNIDIA], with the BOD of 1.56-2.14 mg/L, $\mathrm{NO}_{3}$ concentration of 10.64-13.91 mg/L (mesonitrophilous). A. ambigua and $M$ varians indicate the orthophosphate concentration of $0.21-0.3 \mathrm{mg} / \mathrm{L}$ [108, OMNIDIA].

The meso-eutrophic status at site 1 was indicated by Sellaphora pupula, S. cosntruent, and S. elliptica. This result is in live with the concentration of TN and TP that was in the mesotrophic status (Figs 5, 6).

A neutrophilic $\mathrm{pH}$ at Site 1 was indicated by $A$. microcephala, A. minutissima, A. ambigua, F. capucina, $F$. tenera, S. pupala, and S. pesedoconstruents. Some species such as A. granulata, D. kuetzingii, D. tenuis, $M$. varians, $S$. construents, S. elliptica, and $S$. pinnata indicated alkaliphilic condition at Site 1, whereas at Site 2 in combined with A. granulata, Cocconeis lineata, Diploneis oblongata, F. pinnata, N. rhyncocephala and Rhopaloidea gibba. The occurrence of $A$. microcephala, A. minutissima, A. ambigua, A. granulata, $F$. tennera, Luticula acidoclinata, M. varians, Nitzschia tropica, S. pupula, S. construens, S. elliptica, and S. pseudocosntruens indicated the alcalophilous, $\mathrm{pH}$ in the range of 7.3-7.9, conductivity of 220-600 $\mu \mathrm{s} / \mathrm{cm}[108$, OMNIDIA].

If comparing between sites, TC3 has $43 \%$ a high, $17 \%$ good, $35 \%$ moderate, and $0.4 \%$ poor ecological status (Table 3). Even for Descy and Rott SI indices, all research sites were in a high ecological status, although the percentage of species was $15.33-45.8 \%$.

\section{Relationship of Water Quality Parameter and Diatom Species}

Multivariate statistical analysis approaches were used to evaluate the relationship among water quality parameters $\left(\mathrm{pH}\right.$, turbidity, $\mathrm{TN}, \mathrm{TP}, \mathrm{NH}_{3}, \mathrm{DO}$, and temperature) and diatom assemblages. A total of $44.72 \%$ of cumulative variance was explained by component one and $38.37 \%$ was explained by component two, respectively. The length of its ordination axes was measured with DCA and data produced the gradient length of greater than three standard deviation units ( $>3 \mathrm{SD}$ ), justifying the use of unimodal ordination techniques, furthermore, Canonical Correspondence Analysis (CCA) was chosen [9].

CCA was applied to determine the variation trend of diatoms species to the environmental variables [22]. In the CCA, the eigenvalues of the two axes were calculated as $44.72 \%$ and $38.37 \%$, respectively. The first axis CCA explained $44.72 \%$ of the total variance in species, while the second axis explained $38.37 \%$ of the total variance. Concerning the CCA ordination (Fig. 8) $\mathrm{NH}_{3}$, TP, and $\mathrm{N}$ total were the most

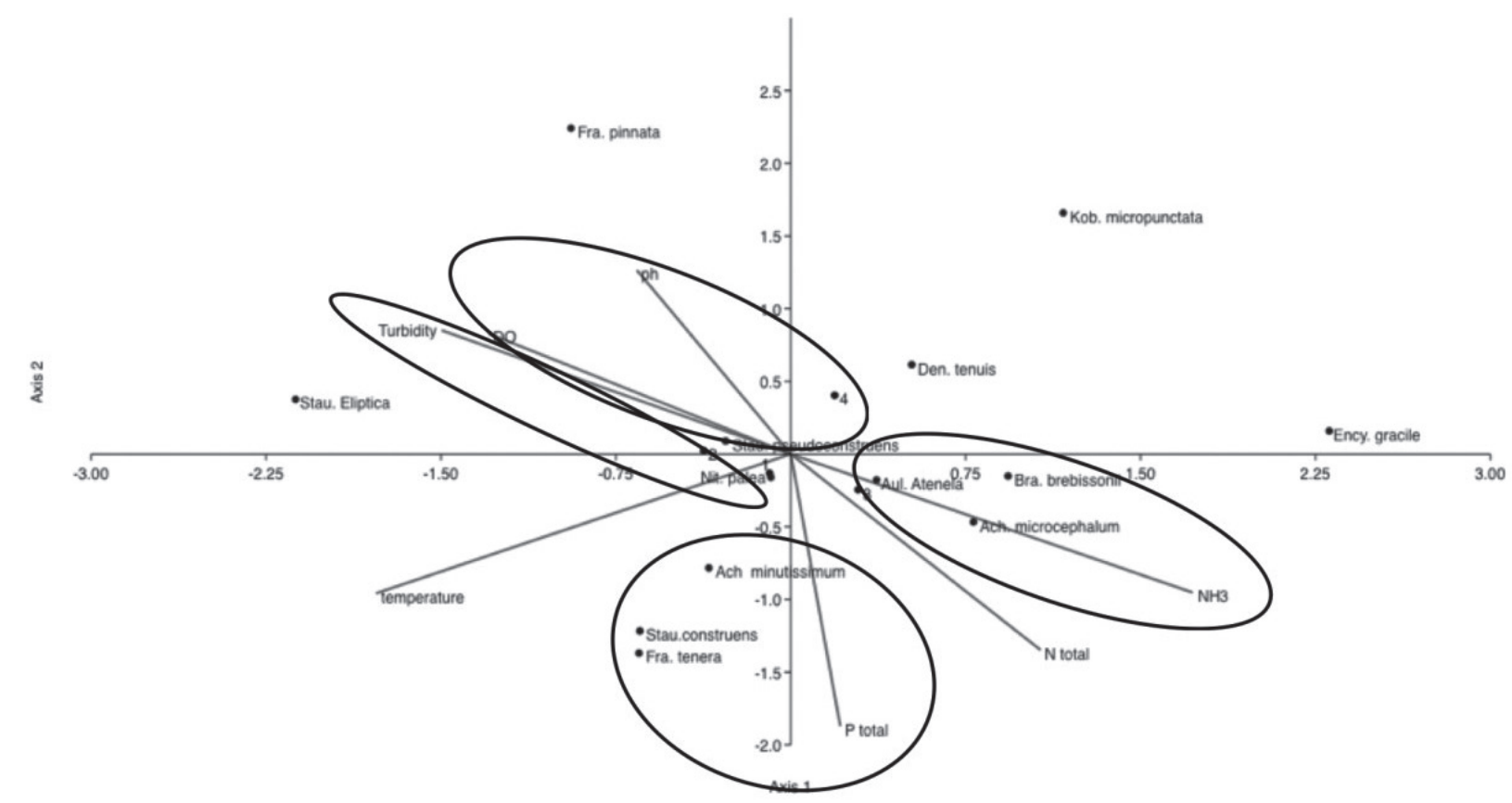

Fig. 8. Cannonical Component Analysis (CCA) between water quality parameters and the relative abundance of diatom $>2 \%$ in Cebong Lake, Dieng. Environmental variables pH, DO, turbidity, temperature, P total, N total, NH3. Diatom species: Fragillaria pinnata, Stauroneis elliptica, Stauroneis pseudocosntruens, Nitzschia palea, Achanthes minutissimum, Stauroneis cosntruens, Fragillaria tenera, Achnanthe microcephalum, Brachysira brebissonii, Aulacoseira ateneia, Denticula tenuis, Kobayashi micropunctata. 
important variable governing the abundance of the diatom. The distribution of main diatom occurrences in the same ordination showed also the proximity of pennate diatoms such as Achanthidium microcephalum, Brachysira brebissoni, Aulacoseira tenella, and Denticula tenuis to the main axis, at the higher $\mathrm{NH}_{3}$, on another hand Staurosira psedoconstruens species were located closer to turbidity, DO and pH. Nitzchia palea abundance was correlated with temperature, while Achanthidium minutissimum, Staurosira construens, and Fragillaria tenera are being closer to each other and were associated mainly with TP (Fig. 8).
The physical and chemical factors investigated in this research have been used to assess the water quality of the aquatic environment in Dieng, based on the given facts $\mathrm{pH}$ of the lake is suitable for agricultural irrigation source present time because the water quality of Cebong lake is neutral alkali lake with $\mathrm{pH}$ around 6, the turbidity result suitable for agriculture source tend to mesotrophic, Dissolved oxygen (DO) is essential for water quality, ecological status, productivity and health of a lake. This is due to its importance as a respiratory gas, and its use in a biological and chemical reaction, Do in Cebong Lake lower than $10 \mathrm{mg} / \mathrm{l}$ indicating healthy for the environment.
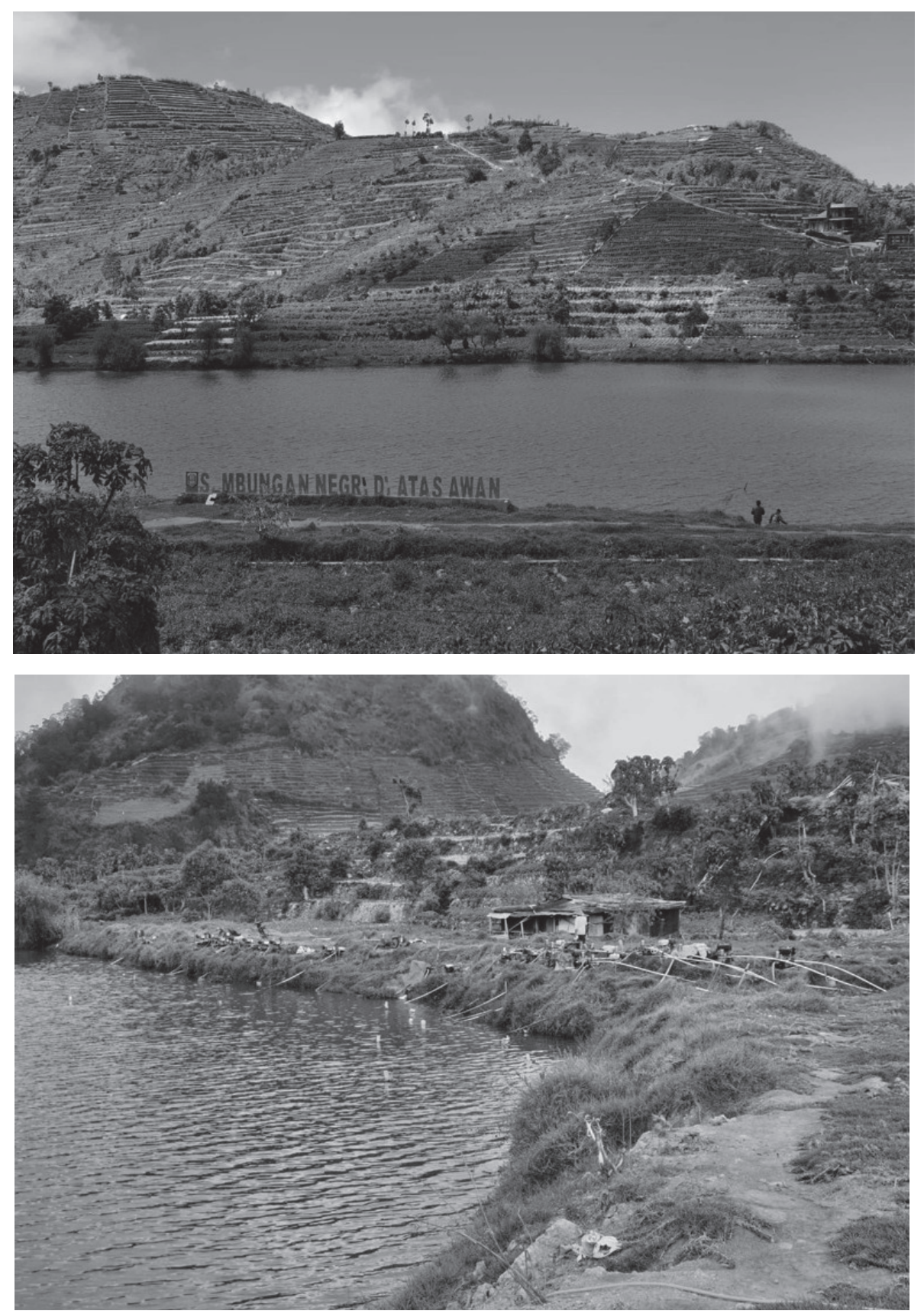

Fig. 9. Cebong Lake surrounded by the hills, erosion problem in wet season, and reducing water volume due to pumping water for irrigation in dry season. 
Cebong Lake is surrounded by the hills that converted for potatoes farm (Fig. 9). In the wet season, erosion cannot be avoided due to limited trees. The problem in the dry season is reducing water volume due to water pumping for irrigation. The nutrient enrichment from fertilizer runoff could stimulate the different diatom assemblages. The diatom composition shows different abundance among area near agriculture, camping area or outlet, whereas the only diatom with wide tolerance dominated in the site with high TP and $\mathrm{NH}_{3}$.

A. minutissimum dominated almost all sampling sites. This species reported has wide tolerance condition from acidic to alkaline and from oligotrophic to hypereutrophic water [109]. Achanthidium mostly found in clean well-oxygenated oligotrophic, alkaline, calcareous, fresh waters with moderately elevated electrolyte content [63]. The abundance of Achanthidium minutissimum is affected by a large number of aquatic plants around the lake. There are water hyacinths on the banks of the Cebong Lake. Achnanthidium is epiphytic (the diatom that attached to the aquatic plant) [110].

Fragillaria pinnata is a solitary species and commonly found in the area with clear water condition from medium to high conductivity. Fragillaria pinnata is an indicator freshwater species with oligotrophicmesotrophic status and lived in littoral area as a periphyton [111]. Staurosira construens showed high abundance in Cebong Lake indicated good water quality [63].

Denticula is often found in the littoral margins of lakes, ponds, and streams [112]. In Indonesia Denticula species are reported from Sumatra and Java, and Denticula van heurckii were found in Bandung, Java by Hustedt [24]. Soeprobowati [43] shown Denticula mostly were found in Warna and Pengilon Lake, Dieng. Denticula lives in specific ecological condition like in mountain lakes or hot springs with a $\mathrm{pH}$ range around 6-8. Denticula found in Blue Lake, Utah America with and altitude more than 1,300 masl. D. vanheurckii, morphologically similar to Epithemia, and proposes as a new genus of Tetralunata that restricted to Java and bali [111]. Toba Lake, Blue Lake, and Cebong relatively have similar environmental charactheristics as a geothermal lake. Overall, based on physical and diatom assemblages Cebong Lake were in oligotrophic condition, the mesotrophic status only in a certain site that closes with agriculture area, supported with diatom abundance data and autecology explanation.

\section{Conclusions}

There were 60 diatom species from 27 genera were identified from Cebong Lake Dieng. The diatom indices that represent $>70 \%$ species from Cebong Lake were IDG, IPS, TDI, IBD. Based on the diatom indices, Cebong Lake was in the $\beta$ mesosaprobic status. This is supported by the concentration of TN and TP that was in the mesotrophic status.

According to the CCA analysis, there is a correlation between water quality parameters and diatom abundance in Cebong Lake. Considering CCA, the abundance of A. microcephalum, B. brebissoni, A. tenella, and Denticula tenuis were correlated $\mathrm{NH}_{3}$ concentration. $S$. psedoconstruens was more influenced by turbidity, DO and $\mathrm{pH}$. The abundance of $N$. palea was correlated with temperature, while A. minutissimum, S. construens, and $F$. tenera were associated mainly with TP.

\section{Acknowledgments}

This study was carried out within the framework of Research of a highly reputable international journal (Riset Publikasi Internasional Bereputasi Tinggi, RPIBT) Universitas Diponegoro, contract number 233-38/UN7.6.1/PP/2020. Deeply thank you to Alam Dilazuardi, Pamrayoga Geyga, Christopher Hardian W, Oki Rachmalia, Wahyu Utari, Safira R and Jihan A during fieldwork and laboratory.

\section{Conflict of Interest}

The authors declare no conflict of interest.

\section{References}

1. ÇADRAKU H., GASHI F., SHALA A., FETOSHI O. Variations in the physico-chemical parameters of under groundwater of Blinaja catchment, Kosovo. IFAC-Papers OnLine. 49 (29), 200, 2016.

2. FORIO M.A.E., GOETHALS P.L.M. An integrated approach of multi-community monitoring and assessment of aquatic ecosystems to support sustainable development. Sustainability. 12 (14), 5603, 2020.

3. ZOLKEFLI N., SHARUDDIN S.S., YUSOFF M.Z.M., HASSAN M.A., MAEDA T., RAMLI N. A review of current and emerging approaches for water pollution monitoring. Water. 12 (12), 3417, 2020.

4. STEVENSON R.J., PAN Y.D., DAM H.V., SMOL J.P., STOERMER E.F. Assessing environmental conditions in rivers and streams with diatoms. Diatoms Appl. Environ. Earth Sci. 2, 57, 2010.

5. MARKERT B., BREURE A.M., ZECHMEISTER H.G. Bioindicators and biomonitors: principles, concepts and applications, Elsevier. Trace Metals and other Contaminants in the Environment. 6, 15, 2003.

6. SOEPROBOWATI T.R., SUWARNO H., GELL P., ZAWADSKI A. The diatom stratigraphy of Rawapening lake, implying eutrophication history. American J. Environ. Sci. 8 (3), 334, 2012a.

7. PARMAR T.K., RAWTANI D., AGRAWAL Y.K. Bioindicators: the natural indicator of environmental pollution. Frontiers in Life Sci. 9 (2), 110, 2016.

8. MENG J., YU Z., MIAO M., KONG Q., ZHANG Y., LIU J. Differentiated responses of plankton and zoobenthos to water quality based on annual and seasonal analysis 
in a freshwater lake. Pol. J. Environ Stud. 26 (2), 755, 2016.

9. OTERLER B. Winter phytoplankton composition occurring in a temporarily ice-covered lake: a case study. Pol. J. Environ. Stud. 26 (6), 2677, 2017.

10. ZENG L., HE F., ZHANG Y., LIU B., DAI Z., ZHOU Q., WU Z. How submerged macrophyte restoration promotes a shift of phytoplankton community in a shallow subtropical lake. Pol. J. Environ. Stud. 26 (3), 1363, 2017.

11. NGUYEN G.T., NHIEN H.T.H. Phytoplankton-water quality relationship in water bodies in the Mekong Delta, Vietnam. Applied Environ. Research. 42 (2), 1, 2020.

12. AUGUSTYN Ł., BABULA A.M., JONIEC J., STANEKTARKOWSKA J., HAJDUK E., KANIUCZAK J. Microbiological indicators of the quality of river water, used for drinking water supply. Pol. J. Environ. Stud. 25 (2), 511, 2016.

13. SAKRAN T., MATOOQ P., SHAHAWY G.E., SHALABY M., SABRY H., GAD M. Monitoring water quality parameters in egyptian tap water. Pol. J. Environ. Stud. 28 (4), 2815, 2019.

14. LOBO J., SHOKRALLA S., COSTA M.H., HAJIBABAEI M., COSTA F.O. DNA metabarcoding for high-throughput monitoring of estuarine macrobenthic communities. Sci. Rep. 7, 15618, 2017.

15. KUNTKE F., DE JONGE N., HESSELSOE M., NIELSEN J.L. Stream water quality assessment by metabarcoding of invertebrates. Eco. Ind. 111, 105982, 2020.

16. CUSTODIO M., CHIRINOS C., PEÑALOZA R. Behavior of physicochemical parameters and potentially toxic metals in surface water evaluated by means of multimetric indices: a case study in a protected natural area of Peru. Pol. J. Environ. Stud. 29 (3), 2111, 2020.

17. BATTARBEE R.W., FLOWER R.J., JUGGINS S., PATRICK S.T., STEVENSON A.C. The relationship between diatoms and surface water quality in the Hoylandet area of Nord-Trondelag, Norway. Hydrobiologia. $348(1 / 2 / 3), 69,1997$.

18. BELLINGER B.J., COCQUYT C., O'REILLY C.M. Benthic diatoms as indicators of eutrophication in tropical streams. Hydrobiologia. 573 (1), 75, 2006.

19. TIBBY J., RICHARDS J., TYLER J.J., BARR C., FLUIN J., GOONAN P. Diatom-water quality thresholds in South Australian streams indicate a need for more stringent water quality guidelines. Marine and Freshwater Research. 71 (8), 942, 2019.

20. SOEPROBOWATI T.R., SUGONDO H., HENDARTO I. B., SUMANTRI I., TOHA B. The potential used of epipelic diatoms as bioindicator of water quality: part 1. J. Coast. Dev. 2 (2), 377, 1999.

21. SOEPROBOWATI T.R., SUWARNO H., GELL P., ZAWADSKI A. The diatom stratigraphy of Rawapening lake, implying eutrophication history. American J. Environ. Sci. 8 (3), 334, 2012.

22. SOEPROBOWATI T.R., DJALAL T.S., SUTIKNO, HADISUSANTO S., GELL P. The water quality parameters controlling diatoms assemblage in Rawapening Lake, Indonesia. J. Inter. Biodiv. 17 (2), 657, 2016.

23. SOEPROBOWATI T.R., SUEDY S.W.A., HADIYANTO, Diatoms and water quality of Telaga Warna Dieng, Java Indonesia. IOP Conference series: Earth and Environ. Sci. 55 (1), 2017.

24. SOEPROBOWATI T.R., SUEDY S.W.A. Diatoms, water quality of Toba Lake and its management. Proceeding 16 World Lake Conference. 2017.
25. XUE H., ZHENG B., MENG F., WANG Y., ZHANG L., CHENG P. Assessment of aquatic ecosystem health of the Wutong river based on benthic diatoms. Water. 11 (4), 727, 2019.

26. VALENTIN V., FRÉDÉRIC R., ISABELLE D., OLIVIER M., YORICK R., AGNES B. Assessing pollution of aquatic environments with diatoms' DNA metabarcoding: experience and developments from france water framework directive networks. Metabarcoding and Metagenomics 3: e39646, 2019.

27. APOTHÉLOZ-PERRET-GENTIL L., BOUCHEZ A., CORDIER T., CORDONIER A., GUEGUEN J., RIMET F., VASSELON V., PAWLOWSKI J. Monitoring the ecological status of rivers with diatom eDNA metabarcoding: a comparison of taxonomic markers and analytical approaches for the inference of a molecular diatom index. Mol. Ecol. 00, 1, 2020.

28. VIRTA L., SOININEN J., NORKKO A. Stable seasonal and annual alpha diversity of benthic diatom communities despite changing community composition. Front. Mar. Sci. 7 (88), 1, 2020.

29. BYTYQI P., CZIKKELY M., SHALA-ABAZI A., FETOSHI O., ISMAILI M., HYSENI-SPAHIU M., YMERI P., KASTRATI E.K., MILLAKU F. Macrophytes as biological indicators of organic pollution in the Lepenci river Basin in Kosovo. J. Freshwater Eco. 35 (1), 105, 2020.

30. DING Y., SUN Y., TANG H., SONG X. Effects of macrophyte species and density on algae inhibition and water purification in submerged macrophyte ponds. Pol. J. Environ. Stud. 29 (5), 3451, 2020

31. LEE S., LEE E., A.N.K. Lotic ecosystem health assessments using an integrated analytical approach of physical habitat, chemical water quality, and fish multimetric health metrics. Pol. J. Environ. Stud. 27 (5), 2113, 2018.

32. KOCIOLEK J.P., BLANCO S., COSTE M., ECTOR L., LIU Y., KARTHICK B., KULIKOVSKIY M., LUNDHOLM N., LUDWIG T., POTAPOVA M., RIMET F., SABBE K., SALA S., SAR E., TAYLOR J., VAN DE VIJVER B., WETZEL C.E., WILLIAMS D.M., WITKOWSKI A., WITKOWSKI J. Diatom Base. Pseudo-nitzschia australis Frenguelli, 1939. 2021. Accessed through: World Register of Marine Species at: http://www.marinespecies.org/aphia.php? (accessed 20 September 2020)

33. GOESSLING J.W., SU Y., CARTAXANA P., MAIBOHM C., RICKELT L.F., TRAMPE E.C.L., WALBY S.L., WANGPRASEURT D., WU X., ELLEGAARD M., KUHL M. Structure-based optics of centric diatom frustules: modulation of the in vivo light field for efficient diatom photosynthesis. New Phytologist. 219 (1), 122, 2018.

34. MEDAREVI'C D.P., LOŠI'C D., IBRI'C, S.R. Diatomsnature materials with great potential for bioapplications. Hemijska Industrija. 70, 613, 2016.

35. GOSS R., WILHELM C., JACOB T. Photosynthesis in diatoms: in handbook of algae science, technology, and medicine. Academic Press. 217, 2020.

36. WAN Q., HAMILTON P.B., FUXING K. Observations on attachment strategies of periphytic diatoms in changing lotic systems (Ottawa, Canada). Nova Hedwigia. 99, 239, 2014.

37. BYTYCI P., YMERI P., CZIKKELY M., FETOSHI O., SHALA-ABAZI A., ISMAILI M., RAMSHAJ Q., MILLAKU F. The Application of Benthic Diatoms in Water Quality Assessment in Lepenci River Basin, Kosovo. J. Ecol. Eng. 20 (11), 43, 2019. 
38. PINSEEL E., VANORMELINGEN P., HAMILTON P.B., VYVERMAN W., VAN DE VIJVER B., KOPALOVA K. Molecular and morphological characterization of the Achnanthidium minutissimum complex (Bacillariophyta) in Petuniabukta (Spitsbergen, High Arctic) including the description of A. digitatum sp. nov. European J. Phycology. 52, 264, 2017.

39. SHEN R., REN H., YU P., YOU Q., PANG W., WANG Q. Benthic diatoms of the Ying river (Huaihe River Basin, China) and their application in water trophic status assessment. Water. 10 (8), 1013, 2018.

40. BELLINGER E.G., SIGEE D.C. Freshwater algae: identification and use as bioindicators. United Kingdom John Wiley \& Sons, 2010.

41. CHRAIBI V.L.S., KIRETA A.R., REAVIE E.D., CAI M., BROWN T.N. A paleolimnological assessment of humanimpacts on Lake Superior. J. Great Lakes Research. 40 (4), 886, 2014.

42. HAMPTON S.E., MCGOWAN S., OZERSKY T., VIRDIS S.G.P., VU T.T., SPANBAUER T.L., KRAEMER B.M., SWANN G., MACKAY A.W., POWERS S.M., MEYER M.F., LABOU S.G., O'REILLY C.M., DICARLO M., GALLOWEY A.W.E., FRITZ S.C. Recent ecological change in ancient lakes. Limnol. Oceanogr. 63 (5), 2277, 2018.

43. SOEPROBOWATI T.R, SUEDY S.W.A., HADIYANTO., LUBIS A.R., GELL P. Diatom assemblage in the $24 \mathrm{~cm}$ upper sediment associated with human activities in Lake Warna Dieng Plateau Indonesia. Environ. Tech. Innov. 10, 3114, 2018.

44. SOEPROBOWATI T.R., SUEDY S.W.A., LUBIS A.A., MILLER J. Pollen and diatom evidence of sea water intrusion, east flood canal (Banjir Kanal Timur), Semarang, Indonesia. Environ. Earth Sci. 79 (19), 462, 2020.

45. LAVOIE I., CAMPEAU S., DRAKULIC Z.N., WINTER J.G., FORTIN C. Using diatoms to monitor stream biological integrity in Eastern Canada: an overview of 10 years of index development and ongoing challenges. J. Sci. Tot. Environ. 475, 187, 2014.

46. MUKAROMAH V.N, HANDOYO J.P. Implementation of spatial planning in the Dieng Plateau Region of Banjarnegara Regency. J. Geo. 19, 1, 2019.

47. HARIYONO E., LILIASARI S. The characteristics of volcanic eruption. Intech Open Publ. 94, 2018.

48. IRHAMNA S.A. The impact of tourism development on the community economicaround tourism area of Dieng Wonosobo Regency. Economics Development Analysis Journal. 6 (3), 320, 2017. https://doi.org/10.15294/edaj. v6i3.22277

49. GRIFFIN C. The Dieng'hazardscape': a political ecology of vulnerability natural hazards in Java's highlands. Environ. Hazards. 1, 2018.

50. HERMAWAN, PRIANTO E., SETYOWATI E. Thermal evaluation on the outside of tourism village Dieng Wonosobo. J. Research and Community Services II. 2 (1), 115, 2014. https://doi.org/10.32699/ppkm.vli2.245

51. SIRAIT P., RIDWAN R.H., BATTISTELLI A. Reservoir modeling for development capacity of Dieng Geothermal Field, Indonesia. Proc. Fourtieth Workshop on Geothermal Reservoir Engineering. 2015.

52. VAN BERGEN J.M., ALAIN B., SRI S., TERRY S., KASTIMAN S. Creater lakes of Java: Dieng, Kelud, Ijen. Excursion Guidebook. IAVCEI General Assembly. 2000.

53. SUDARMADJI, SUPRIYANTO H., LESTARI S. Volcanic lakes in Dieng Plateau: their uses and problems
Teknosains. 5 (1), 36, 2015. https://doi.org/10.22146/ teknosains. 26856

54. SYAFRUDIN R., TAMBUNAN M.P., SUPRIATNA. Model of regional vulnerability against $\mathrm{CO}_{2}$ toxic gas disasters at Mount Dieng (case study: Timbang Crater, Batur Sub District, Banjarnegara District). IOP Conf. Series: Earth Environ. Sci. 311 (1), 2019.

55. NURFAHMIA P., MALIKA R.F., SARIA R.P., NURKHOLIS A. Influence of local wisdom to prevent disappearance of Cebong Lake in Sembungan Village, Wonosobo District. Proc. Inter. Conf on Appropriate Technology Development. Bandung, 165, 2015.

56. SOEPROBOWATI T.R., DJALAL T.S., SUTIKNO., HADISUSANTO S., GELL P. The minimum number of valvas for diatom identification in RawaPening Lake, Central Java. Biotropia. 23 (2), 96, 2016

57. KRAMMER K., LANGE-BERTALOT H. Bacillariophyceae $1^{\text {st }}$ part: Naviculaceae. in: ettl h; Gärtner g; Gerloff j; Heynig h. and Mollenhauer d. (eds.), Freshwater Flora of Central Europe, Vol 2/1, Gustav fischer verlag, Jena, Jena, Germany. 876, 1986.

58. KRAMMER K., LANGE-BERTALOT H. Bacillariophyceae $2^{\text {nd }}$ part: Bacillariaceae, Epithemiaceae, Surirellaceae. in: ettl h; Gärtner g; Gerloff j; Heynig h. and Mollenhauer d. (eds.), Freshwater Flora of Central Europe, Vol 2/2, Gustav fischer verlag, Jena, Germany. 596, 1988.

59. KRAMMER, K., LANGE-BERTALOT H. Bacillariophyceae. $3^{\text {th }}$ part: Centrales, Fragilariaceae, Eunotiaceae. in: in: ettl h. Gerloff j; Heynig h; Mollenhauerd. (eds): Freshwater Flora of Central Europe Fischer Verlag, Stuttgart.2: 576, 1991.

60. KRAMMER K., LANGE-BERTALOT H. Bacillariophyceae $4^{\text {th }}$ part achnanthaceae, kritische erganzungen $\mathrm{zu}$ navicula (lineolatae), gomphonema gesamtliteraturverzeichnis teil 1-4 [second revised edition] [with "ergänzungen und revisionen" by h. lange bertalot]. in: h. ettl et al; Freshwater Flora of Central Europe. spektrum akademischer Verlag Heidelberg. 2 (4), 1, 2004.

61. KRAMMER K., LANGE-BERTALOT H. Bacillariophyceae, $5^{\text {th }}$ part: Freshwater Flora of Central Europe. Springer Spektrum Verlag: Jena, Germany, 2, 311, 2000.

62. TAYLOR J.C., COCQUYT C., MAYAMA S. Navicula nielsfogedii J.C. Taylor \& C. Cocquyt sp. nov; a new diatom (Bacillariophyta) from tropical and sub-tropical Africa. Fottea. 16 (2), 201, 2016.

63. TAYLOR J.C., HARDING W.R., ARCHIBALD C.G.M. An illustrated guide to some common diatom species from South Africa. Republic of South Africa. Water Research Commission Pretoria South Africa, 225, 2007.

64. GELL P., SONNEMAN J.A., REID M.A., ILLMAN M.A., SINCOCK J. An illustrated key to common diatom genera from Southern Australia. Cooperation Research Centre For Freshwater Ecology, Identification Guide No.26, Thurgoona, NSW. 1999.

65. SONNEMAN J.A., SINCOCK A., FLUIN J., GELL P. An illustrated guide to common stream diatom species from temperate Australia. Hurgoona, N.S.W: Cooperative Research Centre for Freshwater Ecology. 11, 1999.

66. BAHLS L.L. Diatoms from western North America 1. Some new and notable biraphid species. Montana diatom collection. Lubrecht \& Cramer, Helena, 57, 2017.

67. GUIRY M.D., GUIRY G.M. Worldwide electronic publication, National University of Ireland, Galway. AlgaeBase. https:www.algaebase.org (accessed on 10 September 2020), 2020. 
68. HAMMER O. PAST: Paleontological statistics software package for education and data analysis version 4.03. 2020. http://download.canadiancontent.net/PAST.html

69. DE CÁCERES, M., JANSEN F. Indicspecies: Relationship between Species and Groups of Sites. Package 'indicspecies' version 1.7.9. 2020 https://cran.r-project. org/web/packages/indicspecies/index.html, access on 2 October 2020

70. LECOINTE C., COSTE M., PRYGIEL J. "Omnidia": Software for taxonomy. Calculation of diatom indices and inventories management. Hydrobiologia 296 (1), 509, 1993.

71. LENOIR A., COSTE M. Development of a practical diatom index of overall water quality applicable to the French National Water Board network. In The Use of Algae for Monitoring Rivers II.; Whitton, B.A., Rott, E., Eds; Institut für Botanik Universität Innsbruck, Schmitten, Austria, 29, 1996.

72. CEMAGREF. Studyof quantitative biological methods for assessing water quality. Lyon Water Quality Report. Rhone Basin Financial Agency. Mediterranean-Corsica Lyon, French, 218, 1982.

73. COSTE M., AYPHASSORHO H. Study of the water quality of the Artois-Piccardie Basin using benthic diatom communities (application of diatomic indices). In Reprot CEMAGREF, Bordeaux; Artois-Picardie Water Agerncy. Douai, France, 227, 1991.

74. DESCY J.P. A new approach to water quality estimation using diatoms. Nova Hedwig. 64, 305, 1979.

75. SLÁDEČEK, V. Diatoms as indicators of organic pollution. Acta Hydrochim Hydrobiol., 14, 555, 1986.

76. LECLERQ L., MAQUET B. Two new chemical and diatomic running water quality indices: Comparison with various existing indices. Cah. Biol. Mar. 303, 1987.

77. PRYGIEL J., COSTE M. Recent trends in monitoring French rivers using algae, especially diatoms. In Use of Algae for Monitoring Rivers II; Whitton, B.A., Rott, E., Eds.; Institut für Botanik. Universität Innsbruck: Schmitten, Austria, 87, 1996.

78. DELL'UOMO A. Assessment of water quality of an Apennine river as a pilot study for diatom-based monitoring of Italian watercourses. In The Use of Algae for Monitoring Rivers II.; Whitton, B.A., Rott, E., Eds.; Institut für Botanik Universität Innsbruck: Innsbruck, Austria, 65, 1996.

79. LOBO E.A., CALLEGARO V.L.M., HERMANY G., BES D., WETZEL C.A., OLIVEIRA M.A. Use of epilithic diatoms as bioindicator from lotic systems in southern Brazil, with special emphasis on eutrophication. Acta Limnol. Bras. 16, 25, 2004.

80. HÜRLIMANN J., NIEDERHAUSER P. Method of analysis and assessment of water courses in Switzerland, Diatom, level $\mathrm{R}$ region. Federal Office for the Environment, Forests and Lanscape. OFEFP: Berne, Switzerland, 111, 2002.

81. ROTT E., PFISTER P., VAN DAM H., PIPP E., PALL K., BINDER N., ORTLER K. Lists of indications for growth algae, Federal Ministry of Agriculture and Forestry. Wienna, Astralia, 248, 1999.

82. ROTT E., HOFMANN G., PALL K., PFISTER P., PIPP E. Lists of indications for algae in Austrian rivers, Part 1: Saprobial indication waer management cadastre, Federal Ministry of Agriculture and Forestry. Wienna, Astralia, 73, 1997.

83. KELLY M.G., WHITTON B.A. The trophic diatom index: A new index for monitoring eutrophication in rivers. J. Appl. Phycol. 7, 433, 1995.
84. DESCY J.P., COSTE M.A. Test of methods for assessing water quality based on diatoms. Verh. Intern. Limnol. 24, 2112, 1991.

85. WATANABE T., ASAI K., HOUKI A. Numerical water quality monitoring of organic pollution using diatom assemblages. Sci. Total Environ. 55, 1, 209, 1986.

86. GOMEZ N., LICURSI M. The Pampean Diatom Index (IDP) for assessment of rivers and streams in Argentina. Aquat. Ecol. 35, 173, 2001.

87. STEINBERG C., SCHIEFELE S. Biological Indication of Trophy and Pollution of Running Waters. Zeitschrift für Wasser- und Abwasser-Forschung, 21, 6, 277, 1988.

88. SCHIEFELE S., SCHREINER C. Use of diatoms for monitoring nutrient enrichment acidification and impact salts in Germany and Austria. In Use of Algae for Monitoring Rivers; Whitton, B.A., Rott, E., Friedrich, G., Eds.; Institut für Botanik Universität Innsbruck: Schmitten, Austria, 193, 1999.

89. ELORANTA P., SOININEN J. Ecological status of some finish rivers evaluated using benthic diatom communities. J. Appl. Phycol. 14, 1, 2002.

90. DUMNICKA E., JELONEK M. KLICH M., KWANDRANS J., WOJTAL A. ŻUREK R. Ichtiofauna i Status Ekologiczny wód Wisły, Raby, Dunajca i Wisłoki; Institute of Nature Conservation, Polish Academy of Science: Kraków, Poland, 164, 2006.

91. CABALLERO M., RODRIGUEZ A., VILACLARA G., ORTEGA B., ROY P., LOZANO-GARCÍA S. Hydrochemistry, ostracods and diatoms in a deep, tropical, crater lake in Western Mexico. J. Limno. 2013.

92. DANLADI BELLO A.A., HASHIM N.B., MOHD HANIFFAH M.R. Predicting impact of climate change on water temperature and dissolved oxygen in tropical rivers. Climate. 5 (3), 58, 2017.

93. NAKHATE A.B., KALE M.K. Studies physic-chemical parameters in Kankaleshwar Lake, Dist. Beed (MS) India. Inter. J. Universal Print. 04 (06), 347, 2018.

94. WANG X., LI J., CHEN J., CIU L., LI W., GAO X., LIU Z. Water quality criteria of total ammonia nitrogen (tan) and un-ionized ammonia $\left(\mathrm{NH}_{3}-\mathrm{n}\right)$ and their ecological risk in the Liao River, China. Chemosphere. 243, 125328, 2020.

95. MoE (Indonesian Ministry of Environment). 2009. In MEF (Ministry of Environment and Forestry). The grand design of Indonesian lakes conservation and rehabititation. Ministry of Environment and Forestry, 94, 2016.

96. SHARMA N., WALIA Y.K. Water quality investigation by physicochemical parameters of Satluj River (Himachal Pradesh, India). Current World Environment. 12 (01), 174, 2017.

97. MARQUARDT G.C., COSTA L.F., BICUDO D.C., BICUDO C.E., BLANCO S., WETZEL C.E., ECTOR L. Type analysis of Achnanthidium minutissimum and A. catenatum and description of A. tropicocatenatum sp. nov. (Bacillariophyta), a common species in Brazilian reservoirs. Plant Ecology and Evolution. 150 (3), 313, 2017.

98. PINSEEL E., VAN DE VIJVER B., KOPALOVA K. Achnanthidium sp. nov. (Achnanthidiaceae, Bacillariophyta), a new representative of the A. pyrenaicum group from Spitsbergen (Svalbard Archipelago, High Arctic). Phytotaxa. 226, 63, 2015.

99. SHEN R., REN H., YU P., YOU Q-M., PANG W., WANG Q-X, Benthic diatoms of the Ying River (Huaihe River Basin, China) and their application in water trophic status assessment. Wa-ter (Basel) 10 (8),1013, 2018. 
100. CROWELL R.M., NIENOW J.A., CAHOON A.B. The complete chloroplast and mitochondrial genomes of the diatom Nitzschia palea (bacillariophyceae) demonstrate high sequence similarity to the endosymbiont organelles of the dinotom durinskia baltica. J. Phycol. 55, 352, 2019.

101. BERE T., TUNDISI J.G. Diatom-based water quality assessment in streams influence by urban pollution: Effects of natural and two selected artificial substrates, Sao Carlos-SP, Brazil. Braz. J. Aquat. Sci. Technol. 15 (1), 54, 2011.

102. BERE T., TUNDISI J.G. Influence of ionic strength and conductivity on benthic diatom communities in a tropical river (Monjolinho), São Carlos-SP, Brazil. Hydrobiologia. 661, 261, 2011.

103. WONDMAGEGN T., MENGISTOU S., BARKER P.A. Testing of the applicability of European diatom indices in the tropical rift valley lake, Lake Hawassa, in Ethiopia, African J. Aquatic Sci. 44, 3, 209, 2019.

104. SOLAK C.N., PESZEK Ł., YILMAZ E., ERGÜL H.A., KAYAL M., EKMEKÇI F., VÁRBÍRÓ G., YÜCE A.M., CANLI O., BINICI M.S. Ács, É. Use of Diatoms in Monitoring the Sakarya River Basin, Turkey. Water 12, 703, 2020.

105. YANG J., JI Y., YAN R., LIU X., ZHANG J., WU N., WANG K. Applicability of Benthic Diatom Indices Combined with Water Quality Valuation for Dish Lake from Nanjishan Nature Reserve, Lake Poyang. Water, 12, 10, 2732, 2020.

106. PASISINGI N., PRATIWI N.T.M., KRISANTI M. The Use of Trophic Diatom Index To...in The Upstream of Cileungsi River, West Java. Ind.Fish.Res.J. 20, 1, 11, 2014.
107. VAN DAM H., MERTENS A. \& SINKELDAM, J. A coded checklist and ecological indicator values of freshwater diatoms from the Netherlands. Netherlands J. Aqua. Ecol., 28, 117, 1994.

108. CARAYON D., TISON-ROSEBERY J., DELMAS F. Defining a new autoecological trait matrix for French stream benthic diatoms. Ecol. Indic. 103, 650, 2019.

109. STEFKOVA E. Epilithic diatoms of mountain lakes of the Tatra Mountains (Slovakia). Biologia, Bratislava. 61, 8, 101, 2006.

110. NOVAIS M.H., JUTTNER I., VAN DE VIJVER B., MORAIS M.M., HOFFMANN L., ECTOR L. Morphological variability within the Achanthidium minutissimum species complex (Bacillariophyta): comparison between the type material of Achanthes minutissima and related taxa and new freshwater Achanthidium species from Portugal. Phytotaxa. 224, 2, 101, 2015.

111. HAMSHER S.E., GRAEFF C.L., STEPANEK J.G., KOCIOLEK J.P. Frustular morphology and polyphyly in freshwater denticula (bacillariophyceae) species, and the description of tetralunata gen. nov. (epithemiaceae, rhopalodiales). Plant Ecology and Evolution. 147, 3, 346, 2014.

112. RIBEIRO L., BROTAS V., RINCÉ Y., JESUS B. Structure and diversity of intertidal benthic diatom assemblages in contrasting shores: a case study from the Tagus estuary. Phycology. 49, 258, 2013. 